the 225 patients admitted with COVID-19 between July and October 2020, 98 patients (44\%) received dexamethasone.

In the face of a pandemic with rapidly evolving data, internal guidelines had a significant impact on the prescribing patterns of the wide range of empiric COVID-19 therapeutics because the validity of these agents was still being evaluated and national consensus guidelines were not yet available. Successful implementation of local guidelines is attributed to a small number of dedicated COVID-19 providers, daily huddles with providers, teaching conferences, and incorporation of care-plan pathway into the electronic medical record. We acknowledge that the lower volume of COVID-19 cases in our region provided a more conducive environment for a meticulous and thoughtful process for guidelines development and implementation. These data exemplify the need for local champions to synthesize available evidence with scientific rigor and implement national guidelines. The limitations of this study include the lack of direct attribution of the internal guidelines to prescribing patterns, but the distribution of medication utilization over time suggests that providers integrated local guidance to inform treatment decisions.

Acknowledgments. We acknowledge the members of the UW Medicine Treatment Guidelines Committee and Clinical Allocation Teams: Fred Buckner, Jeannie Chan, Guang-Shing Cheng, Shireesha Dhanireddy, Terry Gernsheimer, Margaret Green, Robert Harrington, Josh Hill, Rupali Jain, Christine Johnston, H. Nina Kim, David Koelle, Mark Mayo, Manoj Menon, Sylvia LaCourse, Paul Pottinger, Anneliese Schleyer, Mark Tonelli, Alpana Waghmare, Anna Wald, Anne Woolfrey, and Mark Wurfel. We also thank Semhar Nega-Asrat, and Brennen Yasuda for completing the data collection.

Financial support. No financial support was provided relevant to this article.
Conflicts of interest. C.J. has received funding from Gilead for consultation on a non-COVID-19 related project. All other authors report no conflicts of interest relevant to this article.

\section{References}

1. Bedford T, Greninger AL, Roychoudhury P, et al. Cryptic transmission of SARS-CoV-2 in Washington state. medRxiv 2020. doi: 10.1101/2020.04.02. 20051417.

2. Murad MH. Clinical practice guidelines: a primer on development and dissemination. Mayo Clin Proc 2017;92:423-433.

3. World Health Organization. Guidance for managing ethical issues in infectious disease outbreaks. Geneva, World Health Organization, 2016. https://apps. who.int/iris/handle/10665/250580. Published 2016. Accessed March 25, 2021.

4. Bhimraj A, Morgan RL, Shumaker AH, et al. Infectious Diseases Society of America guidelines on the treatment and management of patients with COVID-19. Clin Infect Dis 2020; ciaa478.

5. COVID-19 Treatment Guidelines Panel. Coronavirus disease 2019 (COVID-19) treatment guidelines. National Institutes of Health website. https://www.covid19treatmentguidelines.nih.gov/. Accessed January 20, 2021.

6. Beigel JH, Tomashek KM, Dodd LE, et al. Remdesivir for the treatment of COVID-19: final report. N Engl J Med 2020;383:1813-1826.

7. Coronavirus (COVID-19) update: FDA issues emergency use authorization for potential COVID-19 treatment. US Food and Drug Administration website. https://www.fda.gov/news-events/press-announcements/coronaviruscovid-19-update-fda-issues-emergency-use-authorization-potential-covid-19treatment. Published May 1, 2020. Accessed December 22, 2020.

8. Harris PA, Taylor R, Minor BL, et al. The REDCap consortium: building an international community of software partners. J Biomed Inform 2019. doi: 10.1016/j.jbi.2019.103208.

9. RECOVERY Collaborative Group, Horby P, Lim WS, et al. Dexamethasone in hospitalized patients with COVID-19-preliminary report. N Engl J Med 2021;384:693-704.

\title{
The first use of face mask in the history of medicine
}

\author{
Ali Taghizadieh MD¹, Javad Ghazi-Sha'rbaf $\mathrm{PhD}^{2}$, Reza Mohammadinasab $\mathrm{PhD}^{3}$ (1) and Saeid Safiri PhD ${ }^{4,5}$ (1) \\ ${ }^{1}$ Tuberculosis and Lung Disease Research Center, Tabriz University of Medical Sciences, Tabriz, Iran, ${ }^{2}$ Department of Islamic History and Civilization, Faculty of \\ Theology, Azarbaijan Shahid Madani University, Tabriz, Iran, ${ }^{3}$ Department of History of Medicine, School of Traditional Medicine, Tabriz University of Medical \\ Sciences, Tabriz, Iran, ${ }^{4}$ Social Determinants of Health Research Center, Department of Community Medicine, Faculty of Medicine, Tabriz University of Medical \\ Sciences, Tabriz, Iran and ${ }^{5}$ Rahat Breath and Sleep Research Center, Aging Research Institute, Tabriz University of Medical Sciences, Tabriz, Iran
}

To the Editor-Since human life began, epidemics have been a threat to human health. ${ }^{1}$ Today, coronavirus disease 2019 (COVID-19) has spread almost all over the entire world, and apparently one of the most important ways to prevent the transmission of severe acute respiratory coronavirus virus 2 (SARS-CoV-2) is by wearing a face mask. ${ }^{2}$ A face mask largely prevents the transfer of airborne particles to the human respiratory system and can therefore play a significant role in preventing the spread respiratory viruses during epidemics. ${ }^{3,4}$

Interestingly, the mask has been used since ancient times in Iran; however, it should not be confused with the clothing used for women's face veil. The word equivalent to the mask in ancient and medieval Iran was panam or pandam, which is also mentioned

Authors for correspondence: Reza Mohammadinasab and Saeid Safiri. Emails: Rmn. nasab@tbzmed.ac.ir; safiris@tbzmed.ac.ir

Cite this article: Taghizadieh A, et al. (2022). The first use of face mask in the history of medicine. Infection Control \& Hospital Epidemiology, 43: 961-962, https://doi.org/ $10.1017 /$ ice.2021.157 in the Avesta, ${ }^{5}$ the holy book of Zoroastrians, in the religious rituals of the followers of the ancient prophet of Iran. ${ }^{6}$ The Iranian word panam is used in most middle and modern Iranian languages and dialects. This word in the Avestan language means holder and keeper against something, and the Pahlavi Persian language includes the words padam, pandam, and phanom.

According to Pahlavi texts, the panam, now called the veil by Iranian Zoroastrians, refers to 2 pieces of white cotton cloth that are hung over the mouth and tied with 2 ribbons at the back. This small cotton curtain, which according to the Pahlavi interpretation of the description in the Avesta, should be 2 inches below the mouth and should be used when the priest performs a religious ceremony in front of the sacred fir. In fact, the use of panam was to prevent the breath and steam of the mouth, which was considered polluted, from reaching the sacred element of fire. Therefore, it was a religious device of priests. ${ }^{6}$

Also, ancient Iranians who were honored by the king had wear a panam in front of their mouths to show respect for the king. 


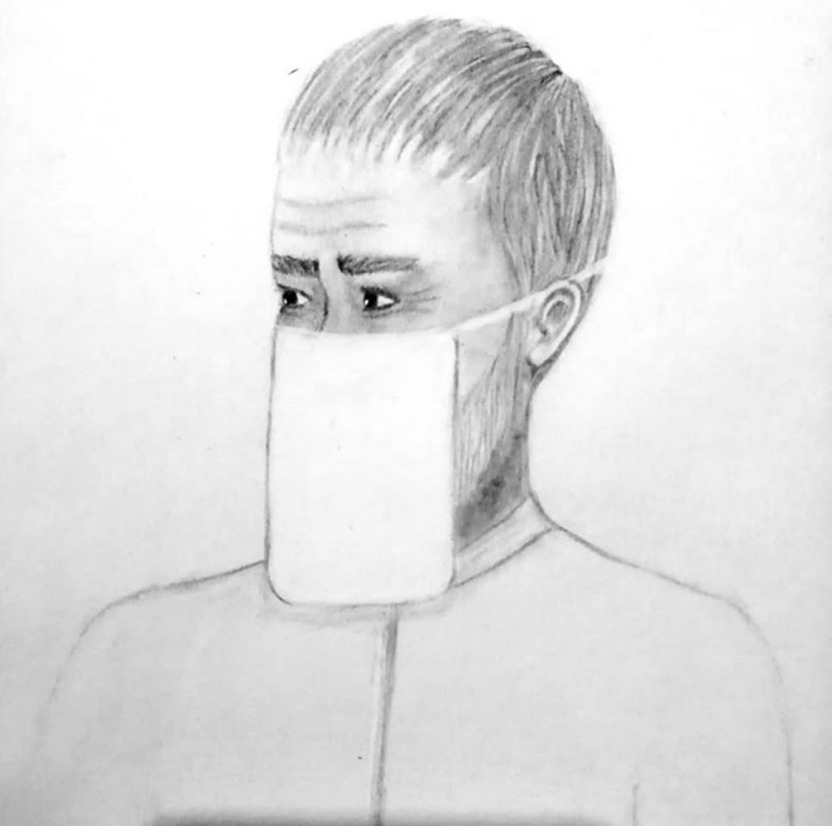

Fig. 1. Schematic representation of face mask by Iranian Zoroastrians.

Ancient Iranian physicians, after observing and treating a patient with an infectious disease, did not immediately treat another patient; first, they cleaned themselves as much as possible to prevent transmission of the disease. During treatment, they wore a scarf or cloth to prevent contamination. The cloth, which covered the face from the protrusion of the nose to under the chin and fastened with strings at the back of the head, seems to be very similar to today's surgical masks (Fig. 1). ${ }^{7,8}$

The constant medical use of panam is also recorded throuhgout the Middle Ages. One of the most famous physicians of the 15th century, Baha al-Dawla Razi, recommended that people wrap a piece of cloth around their airways and soak it in vinegar, onion, and garlic to prevent the spread of diseases (Fig. 2). ${ }^{9}$ This recommendation seems to be the most significant medical advice to prevent respiratory diseases in Iranian medicine. , $^{810}$

Acknowledgments. We would like to thank Dr. Touraj Daryaee for reading our article.

Financial support. No financial support was provided relevant to this article.

Conflicts of interest. All authors report no conflicts of interest relevant to this article.

\section{References}

1. Jones DS. History in a crisis-lessons for COVID-19. N Engl J Med 2020; 382:1681-1683.

2. Bundgaard H, Bundgaard JS, Raaschou-Pedersen DET, von Buchwald C, Todsen T, Norsk JB, et al. Effectiveness of adding a mask recommendation to other public health measures to Prevent SARS-CoV-2 infection in Danish mask wearers: a randomized controlled trial. Ann Intern Med 2021;174: 335-343.

3. Loeb M, Dafoe N, Mahony J, et al. Surgical mask vs N95 respirator for preventing influenza among healthcare workers: a randomized trial. JAMA 2009;302:1865-1871.

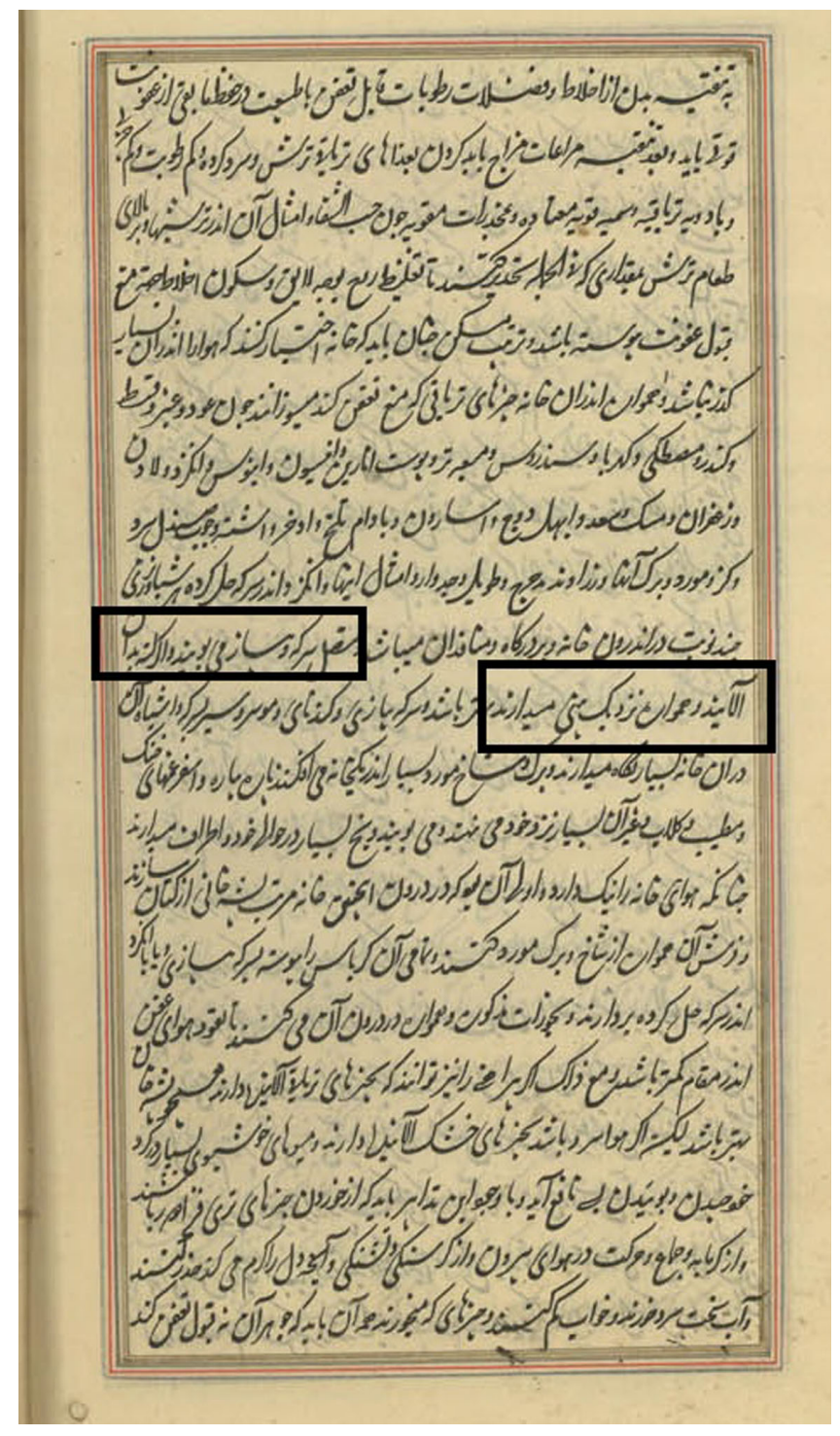

Fig. 2. Mask use instructions in the 15 th century suggested by Baha al - Dawla Razi (http://172.17.20.22:8888/site/catalogue/491189).

4. Institute of Medicine (US) Committee on Personal Protective Equipment for Healthcare Personnel to Prevent Transmission of Pandemic Influenza and Other Viral Respiratory Infections: Current Research Issues. Preventing Transmission of Pandemic Influenza and Other Viral Respiratory Diseases: Personal Protective Equipment for Healthcare Personnel: Update 2010. Larson EL, Liverman CT, editors. Washington, DC: National Academies Press; 2011.

5. Speigel, F. Avesta: The Religious Books of the Parsees. From Professor Spiegel's German Translation of the Original Manuscripts. Muncherjee Hormusjee Cama, 1864.

6. Boyce M. Zoroastrians: Their Religious Beliefs and Practices. New York: Routledge, 2001.

7. Elgood C. Medicine in Persia. New York: Paul B. Hoeber; 1934.

8. Elgood C. Safavid Medical Practice: Or, The Practice of Medicine, Surgery and Gynaecology in Persia Between 1500 A.D. and 1750 A.D. London: Luzac; 1970.

9. Kholasat al-Tajarob, RB. A summary of experiences in medicine. Tehran: Tehran University of Medical Sciences, 2011.

10. Elgood C. A Medical History of Persia and the Eastern Caliphate: From the Earliest Times Until the Year A.D. New York: Cambridge University Press; 2010 . 